Pesq. Vet. Bras. 38(2):271-276, fevereiro 2018

DOI: $10.1590 / 1678-5150-P V B-4860$

\title{
Defined and undefined commercial probiotics cultures in the prevention of Salmonella Enteritidis in broilers ${ }^{1}$
}

\author{
Erich H. Carvalho ${ }^{2}$, Angélica S. Mendes ${ }^{3 *}$, Sabrina E. Takahashi ${ }^{4}$, \\ Rosângela A.B. Assumpção ${ }^{5}$, Douglas V. Bonamigo ${ }^{4}$, Daniel Müller ${ }^{4}$ and Rosana R. Sikorski ${ }^{4}$
}

\begin{abstract}
Carvalho E.H., Mendes A.S., Takahashi S.E., Assumpção R.A.B., Bonamigo D.V., Müller D. \& Sikorski R.R. 2018. Defined and undefined commercial probiotics cultures in the prevention of Salmonella Enteritidis in broilers. Pesquisa Veterinária Brasileira 38(2):271-276. Departamento de Agronomia, Universidade Tecnológica Federal do Paraná, Estrada para Boa Esperança Km 4, Cx. Postal 157, Dois Vizinhos, PR 85660-000, Brazil. E-mail: angel.concordia@hotmail.com

This study aimed to evaluate the efficacy of probiotics from different formations, defined and undefined cultures, applied in the control of Salmonella Enteritidis in broilers, identifying the compositions and states for which the probiotics are more effective. For that, 390 broilers were inoculated orally with $1.00 \mathrm{ml}$ of Salmonella Enteritidis at a concentration of $1.2 \times 10^{9} \mathrm{CFU}$ (Colony Forming Units). The experimental design used was randomized blocks with 5 treatments and 6 replications, totaling 30 boxes with 13 birds/box ( 13 birds $/ \mathrm{m}^{2}$ ). The treatments were provided via drinking water 1 hour after inoculation, keeping a daily treatment of 12 hours with probiotics, for 3 consecutive days (birds at 1, 2 and 3 days of age). In general, the five treatments conducted were: T1 - Control without probiotic, T2 - Probiotic A (defined culture - lyophilized form, strain 7), T3 - Probiotic B (defined culture - lyophilized form, strain 11), T4 - Probiotic C (undefined culture liquid form), T5 - Probiotic D (undefined culture - liquid form). After treatments, performance was evaluated through average body weight, feed conversion and mortality counting. Microbiological analysis and Salmonella isolation were performed using MPN (Most Probable Number) and selective enrichment technique methods, respectively. Samples of ileum and liver pool, cecal tonsils, cecum, heart and spleen pool were collected at 5 and 31 days of age. No differences were observed on growth performance and isolation of Salmonella Enteritidis $(\mathrm{p} \geq 0.05)$. All probiotics applied were effective on reducing Salmonella Enteritidis colonization in the ileum, cecal tonsils, and cecum at 5 days of life. Probiotics T2 and T5 has shown effectiveness in reducing colonization at 31 days, being considered the most efficient on Salmonella Enteritidis control, for the intestines segments evaluated. It was not possible to affirm which probiotics formation, defined or undefined, is more efficient for Salmonella Enteritidis control.
\end{abstract}

INDEX TERMS: Probiotics, Salmonella Enteritidis, broilers, bird health, food safety, control, bacterioses.

\footnotetext{
${ }^{1}$ Received on July 4, 2016.

Accepted for publication on March 18, 2017.

${ }^{2}$ Programa de Pós-Graduação em Zootecnia (PPGZO), Universidade Tecnológica Federal do Paraná UTFPR), Estrada para Boa Esperança Km 4, Cx. Postal 157, Dois Vizinhos, PR 85660-000, Brazil.

${ }^{3}$ Departamento de Agronomia, UTFPR, Estrada para Boa Esperança Km 4, Cx. Postal 157, Dois Vizinhos, PR 85660-000. * Corresponding author: angelica@utfpr.edu.br

${ }^{4}$ Departamento de Zootecnia, UTFPR, Campus Dois Vizinhos, Estrada para Boa Esperança Km 4, Cx. Postal 157, Dois Vizinhos, PR 85660-000.

${ }^{5}$ Departamento de Tecnologia Alimentar, UTFPR, Campus Toledo, Rua Cristo Rei 19, Vila Becker, Toledo, PR 85902-490, Brazil.
}

RESUMO.- [Probióticos comerciais de culturas definidas e indefinidas na prevenção de Salmonella Enteritidis em frangos de corte.] 0 objetivo deste trabalho foi avaliar a eficácia dos probióticos de diferentes constituições: de culturas definidas e de culturas indefinidas no controle de Salmonella Enteritidis em frangos de corte, identificando qual a constituição e qual ou quais probióticos testados é mais eficaz. Foram inoculados 390 frangos de corte com $1 \mathrm{ml}$ de Salmonella Enteritidis, via oral, na concentração de 1,2 x $10^{9}$ UFC (Unidades Formadoras de Colônia). 0 delineamento experimental utilizado foi o de blocos casualizados com 5 tratamentos e 
6 repetições cada, totalizando 30 boxes com 13 aves/boxe (13 aves $/ \mathrm{m}^{2}$ ). Os tratamentos foram fornecidos via água de bebida 1 hora após a inoculação, com 12 horas de tratamento com probióticos por dia, durante 3 dias consecutivos $\left(1^{\circ}, 2^{\circ}\right.$ e $3^{\circ}$ dia de idade das aves). Os cinco tratamentos foram: T1 - Controle sem probiótico, T2 - Probiótico A (cultura definida - forma liofilizada, 7 cepas), T3 - Probiótico B (cultura definida - forma liofilizada, 11 cepas), T4 - Probiótico C (cultura indefinida - forma líquida), T5 - Probiótico D (cultura indefinida - forma liofilizada). 0 desempenho zootécnico foi avaliado usando o peso médio, a conversão alimentar e a mortalidade. Análises microbiológicas foram realizadas utilizando o método NMP (NMP/g)e isolamento de Salmonella através técnica de enriquecimento seletivo. Amostras de pool de íleo, tonsilas cecais e cecos e pool de fígado, coração e baço foram coletadas aos 5 dias e aos 31 dias de idade. Para desempenho zootécnico e isolamento de Salmonella Enteritidis não foram observadas diferenças $(\mathrm{p} \geq 0,05)$. Todos os probióticos utilizados foram eficazes na redução da colonização de Salmonella Enteritidis no íleo, tonsilas cecais e cecos aos 5 dias de idade e somente os probióticos do T2 (cultura definida) e T5 (cultura indefinida) reduziram a colonização aos 31 dias sendo considerados os mais eficazes no controle de Salmonella Enteritidis nestes segmentos intestinais avaliados. Não se pode afirmar quais das constituições de probióticos, culturas definidas ou indefinidas, são mais eficazes no controle de Salmonella Enteritidis.

TERMOS DE INDEXAÇÃO: Probióticos comerciais, Salmonella Enteritidis, frangos de corte, saúde das aves, segurança alimentar, bacterioses.

\section{INTRODUCTION}

In public health, Salmonella emerges with great influence due to its wide occurrence in humans and animals, being birds considered the central agent in the epidemiology of enteric Salmonellosis, representing a reservoir of sanitary importance and considerably hard to control (Borsoi et al. 2010).

The genus Salmonella belongs to the Enterobacteriaceae family and comprises the species Salmonella enterica and Salmonella bongori, being the species Salmonella enterica divided into six subspecies: enterica, salamae, arizonae, diarizonae, houtenae and indica (Bopp et al. 2003), which includes Salmonella enterica subspecie enterica serovar Enteritidis (Pickler et al. 2011). Salmonella Enteritidis and Salmonella Typhimurium are the major serovars found in birds that are connected to cases of Salmonellosis in humans (Borsoi et al. 2011).

Serovars prevalent in humans, such as Enteritidis and Typhimurium, are common in broiler chickens (Gast et al. 2007). Currently, the genus Salmonella spp. is consisted by 2,610 serovars (Guibourdenche et al. 2010) from which approximately $10 \%$ have been isolated from birds and only a small portion is frequent in broiler chicken farms.

In recent years, the use of antimicrobials, attenuated and inactivated vaccines for preventing or limiting infection from Salmonella spp., has been questioned due to the development of antibiotic resistance, as well as its potential risks of residues and adjuvants from vaccines in animal-derived food products for human consumption (Hasenstein et al. 2006). For this reason, its use has been gradually restricted, and other tools for disease control has been tested, from which can be highlighted: competitive exclusion, controlled probiotics, and prebiotics (Rahimi et al. 2007).

Probiotic cultures, consisting of live and viable microorganisms, generally found in the gastrointestinal tract or outer life (e.g., Bacillus subtilis and Bacillus licheniforms), have been evaluated successful for this purpose. These probiotics may be classified as undefined cultures, in which not all of its microorganisms are known, or defined cultures with known composition (Schrezenmeir \& Devrese 2001).

As a general definition, probiotics are additives composed by microorganisms that, when administrated on adequate quantities, are beneficial to the host's health, modulating the immune system (Gaggía et al. 2010). Regarding to birds feeding, species receiving probiotics shows favorable effect on the zootechnic performance, intestinal microbiota modulating, and inhibition of pathogens, Intestinal histologic changes, immunomodulation, hematological and biochemical parameters and sensory characteristics of meat (Lutful Kabir 2009).

In this scope, this work evaluates the effectiveness of commercial probiotics from defined and undefined cultures in control of Salmonella Enteritidis in broilers, identifying the most effective probiotic and its respective composition.

\section{MATERIALS AND METHODS}

The experiment was conducted in the experimental poultry house Laboratório de Inovações Avícolas (Poultry Innovations Lab)/LINAV UTFPR - Campus Dois Vizinhos. A total number of 390 female broilers with average initial weight of $47.37 \pm$ $0.31 \mathrm{~g}$ were used. The animals were from the lineage Cobb 500, vaccinated in the hatchery against Marek's disease, Fowl pox, and Infectious Bronchitis. The birds were kept from the $1^{\text {st }}$ to the $31^{\text {st }}$ day of life in ideal temperature comfort according to the age, with water and feed supply at will, the diets were formulated according to the nutritional requirements developed by Rostagno et al. (2005).

The experimental design used was randomized blocks with 5 treatments and 6 repetitions each, totaling 30 boxes with 13 birds/box (density of $13 \mathrm{birds} / \mathrm{m}^{2}$ ). After the experimental design defined, birds were distributed randomly in the experimental units. The five treatments applied were: T1 - Control without probiotic, T2 - Probiotic A (defined culture, lyophilized form, 7 strains: Lactobacillus plantarum, Lactobacillus bulgarincus, Lactobacillus acidophilus, Lactobacillus rhamnosus, Bifidobacterium bifidum, Streptococcus thermophilus, Enterococcus faecium), T3 - Probiotic B (defined culture, lyophilized form, 11 strains: Lactobacillus bulgaricus (3 strains), Lactobacillus casei (2 strains), Lactobacillus cellobiosus (2 strains), Lactobacillus fermentum (3 strains) and Lactobacillus helveticus (1 strains), T4 - Probiotic C (undefined culture, liquid form, intestinal microflora of poultry SPF (Specific Pathogen Free) anaerobic bacteria, bacteria from genus Enterococcus and lactic acid producing bacteria), T5 - Probiotic D (undefined culture, lyophilized form, intestinal microflora of poultry SPF. All probiotics used in this work are commercial products available in the Brazilian market and registered in Ministry of Agriculture, Livestock and Supply and the dosage used was recommended by the manufacturer. All treatments were provided via drinking water, starting 1 hour after inoculating Salmonella Enteritidis, and lasting for 12 hours a day, for 3 consecutive days (days 1, 2 and 3 of life). The necessity of water to be supplied was calculated to guarantee complete ingestion of the solution. The experimental design is summarized in Table 1. 
Table 1. Summary of the experimental delineation with the respective analyzes and frequencies

\begin{tabular}{|c|c|c|c|c|c|c|}
\hline \multirow[t]{2}{*}{ Treatment } & \multirow[t]{2}{*}{ Repetitions } & \multirow[t]{2}{*}{ Birds/treatment } & \multicolumn{2}{|c|}{$\begin{array}{l}\text { MPN/g Ileum, Cecum, and Cecal Tonsils Pool / } \\
\text { MPN/g Heart, Liver and Spleen Pool }\end{array}$} & \multirow{2}{*}{$\begin{array}{c}\text { Litter Swabs } \\
12 \text { days }\end{array}$} & \multirow{2}{*}{$\begin{array}{c}\begin{array}{c}\text { Zootechnic Performance } \\
\text { (Average Weight, Feed } \\
\text { Conversion and Mortality) }\end{array} \\
1-31 \text { days }\end{array}$} \\
\hline & & & 5 days & 31 days & & \\
\hline $\mathrm{T} 2$ & 6 & 78 & 12 birds & 12 birds & - & - \\
\hline T3 & 6 & 78 & 12 birds & 12 birds & - & - \\
\hline $\mathrm{T} 4$ & 6 & 78 & 12 birds & 12 birds & - & - \\
\hline
\end{tabular}

The strain of Salmonella Enteritidis, isolated from a field sample resistant to nalidixic acid $(100 \mu \mathrm{g} / \mathrm{ml}$ medium $)$, was recovered from lyophilized cultures. Upon accommodation, all birds were inoculated with $1 \mathrm{ml}$ of a solution containing $1.2 \times 10^{9}$ CFU Salmonella Enteritidis/ml using a $3 \mathrm{ml}$ sterile pipette via gavage.

In order to evaluate the zootechnical performance, the variable to be assessed were defined: average weight at $1 \mathrm{st}^{\mathrm{t}}$, 5 th, 7 th, 14th, 21st, 28th and 31st days of age, mortality and Total feed conversion according to the methodology proposed by Miragliotta (2005). At 5 days of age (120 hours after inoculation) and at 31 days of age (slaughter of birds), 12 birds per treatment per age ( 2 birds randomly chosen of each repetition) were euthanized by cervical dislocation and autopsied to collect organs aseptically. At 12 days of age, swab collection was held in all 30 boxes for isolation of Salmonella Enteritidis.

To evaluate the effectiveness of treatments related to Salmonella Enteritidis colonization in the gastrointestinal tract culture, samples from ileum pool, cecum and cecal tonsils were obtained. Regarding the invasion of internal organs, culture samples were taken from liver, heart and spleen pool. On the evaluation of colonization of the gastrointestinal tract and invasion of internal organs, the most probable number (MPN) methodof bacterial cells per gram was performed, expressed in MPN/g, to bacterial cell counting and the selective enrichment technique of the semi-solid Modified Rappaport Vassiliadis (MSRV) for the isolation of Salmonella Enteritidis, expressed in \% positive. The MPN method of bacterial cells per gram was adapted from the protocol recommended by the MAPA (2003). The microbiological analyses were performed on an Animal Health Laboratory recognized by the Ministry of Agriculture, Livestock and Supply (MAPA) of a poultry company in Brazil.

After confirming the growth of Salmonella spp. the number of positive, indicating evidence of Salmonella Growth, for the series of five tubes was reported, along with the results for the $6^{\text {th }}$ tube. The final composition of reading series was compared with the table of DeMan (1983) in which the MPN per gram is established with different confidence intervals. The isolation of Salmonella Enteritidis was conducted by the technique of selective enrichment in semi-solid medium Modified Rappaport Vassiliadis (MSRV) (Koerich 2007).

The results for growth performance were subjected to analysis of variance (ANOVA) using software R Development Core Team (2005). The averages of MPN counting of Salmonella Enteritidis were transformed by applying box-cox (lambda) transforming, held ANOVA and compared by Duncan test at $5 \%$ probability for treatments with the same number of portions and Scheffé test of averages at 5\% to treatments with a different number of parts. The results of Salmonella Enteritidis isolation were compared using the chi-square test $\left(\chi^{2}\right)$ to $5 \%$. All analyses were performed using the statistical program R Development Core Team $^{\circledR}$.

\section{RESULTS AND DISCUSSION}

During the experiments, it was not observed significantly differences on the zootechnic performance for food conversion, \% mortality and average weight through the different ages assessed. Our zootechnic performance results are similar to results obtained by Rossi et al. (2007), which states that the greatest part of current publications related to Salmonella challenge do not show any differences in the zootechnic performance of animals, and the papers that presented differences did not submit the animals to a sanitary challenge. This dichotomy between zootechnic and sanitary data increases the difficulty of comparison of the results obtained by different authors. Fact that also occurs in other studies involving control of Salmonella, such as the use of organic acids that, according to Pickler et al. (2012), when evaluating the performance o this acid in broilers, has found controversial results, probably due to different experimental design, environmental designs, quantities, type of products utilized and parameter of evaluation.

Opposite to the results found for zootechnic performance, authors report the influence of various probiotics on the productivity of the animals, checking a positive effect, particularly those using probiotics of defined cultures (Mountzouris et al. 2010). According to Tellez et al. (2012) trials in commercial scale indicated that the proper administration of probiotic cultures defined for turkeys and chickens, improved growth performance and reduced production costs. According to these authors, the data clearly demonstrate that the selection of probiotic cultures for therapeutic efficacy promotes outstanding benefits in the performance of the birds and that the defined cultures can provide an attractive alternative to conventional antimicrobial therapy.

Regarding the probiotics from undefined cultures, the literature does not indicate any improvement in growth performance (Al-Zenki et al. 2009), which agrees with the results found in this study, using probiotics of indefined culture. Bittencourt et al. (2011), when evaluating the addition of probiotic product containing Lactobacillus acidophilus, Streptococcus faecium, and Bifidobacterium bifidum from 1 to 42 days of age for broiler chickens, found no influence on the growth performance of birds. Silva et al. (2011) used the same probiotic product with 
same concentrations but found better growth performance in the period from 0 to 21 day in chickens fed with probiotics.

Moreover, this variability of performance results in thi investigation and other experiments described in the literature may be due to factors related to the product and its manufacturing process, the type of organism, the method of production of probiotic and viability after preparation, management factors, route of administration, form of presentation (liquid or lyophilized), precocity of the Administration, use of antibiotics, the combination with Prebiotics Since some have a synergistic effect (Vicente et al. 2007).

Regarding the isolation of Salmonella Enteritidis, it was found that all challenged groups presented some presence of Salmonella Enteritidis evaluated at different ages ( 5 and 31 days) and analyzed material (organs pool and little swabs). (Table 2)

No significant differences for the isolation of Salmonella Enteritidis in relation to the colonization of the gastrointestinal tract were found (ileum pool, cecum and cecal tonsils) and in relation to invasion of internal organs (liver, heart and spleen pool) at 5 and 31 days of age in any of the probiotics used in the control group.

Although there is a numerical reduction in the isolation of Salmonella Enteritidis at 5 days of age in ileum pool, cecum and cecal tonsils by all probiotics used compared to the control, and T5 (lyophilized undefined culture) reduced $50 \%$, T2, and T3 (defined cultures) decreased $42 \%$ and $\mathrm{T} 4$ (liquid undefined culture) declined 25\%, showed no statistical difference $(\mathrm{p} \geq 0.05)$.

These results can be based on the fact of Salmonella Enteritidis have high invasiveness and enter the cecal mucosa (Berndt et al. 2006). Borsoi et al. (2011) analyzing the behavior of Salmonella Enteritidis after inoculation of $10^{5} \mathrm{CFU} / \mathrm{ml}$ in broiler chickens with a day of age demonstrated its presence in the liver and cecum 6 hours after inoculation. Also the fact that pre-exposure to Salmonella before treatment with probiotics of undefined cultures can substantially reduce the protection (Revolledo et al. 2006).

The high bacterial concentration used in the challenge of birds $\left(1.2 \times 10^{6} \mathrm{CFU} / \mathrm{ml}\right)$ and the use of probiotics in an individualized way may also have contributed to this minor reduction of intestinal colonization and invasion of organs. Revolledo et al. (2009), using $10^{7} \mathrm{CFU} / \mathrm{ml}$ of Salmonella Typhimurium, evaluated the effect of a defined probiotic culture (12 strains) a $\beta$-glucan abiotic (Goldcell-Biorigin ${ }^{\circledR}$ ) and a probiotic of an undefined culture (Aviguard ${ }^{\circledR}$ ) administered alone or in association. Such evaluations showed that the probiotic of an undefined culture, probiotic of a defined culture and glucans were not effective in preventing colonization and invasion of organs in birds with a high challenge, but were effective when treatments were associated with probiotics of undefined cultures, probiotic of defined culture and glucan. Estrada et al. (2010), when evaluating the effects of a probiotic of a defined culture (Broilact ${ }^{\circledR}$ ) and a probiotic of an undefined culture (Aviguard ${ }^{\circledR}$ ), both supplied at 1 day of age, on the invasion and colonization of Salmonella Enteritidis $\left(1 \times 10^{8} \mathrm{CFU} / \mathrm{ml}\right)$, did not find significant differences at 12 days of age on the Salmonella Enteritidis invasion in the liver and spleen and cecal tonsils colonization. Only at 20 days of age, the probiotic of a defined culture presented a reduction of $15 \%$ more in the liver and spleen invasion by Salmonella than the probiotic of an undefined flora.

Vincente etal. (2008) evaluated a probiotic of defined culture (Floramax ${ }^{\circledR}$ B11) in liquid and lyophilized form via drinking water for three consecutive days ( 1 to 3 days of age). The birds challenged with $10^{4} \mathrm{CFU} /$ bird of Salmonella Enteritidis 1 hour before the start of treatment, showed significant reduction in Salmonella Enteritidis colonization in young birds.

Our results did not show significantly differences regarding invasion of internal organs (liver, hearth and spleen pool) at day 5th in any treated group, similar to results obtained by Revolledo et al. (2009), that evaluated the effect of a probiotic in a defined culture (12 strains), a $\beta$-glucan abiotic (Goldcell-Biorigin ${ }^{\circledR}$ ) and a probiotic in an undefined culture $\left(\right.$ Aviguard $^{\circledR}$ ) administered alone or in combination and showed that the invasion of spleen in the groups treated with probiotics alone was higher than the control group, and that also did not prevent the invasion in the liver. At day 31th significantly differences were found between the control and other probiotics, where control group had the lowest score. These results do not characterize effectiveness in controlling Salmonella Enteritidis by probiotics used against the invasion of internal organs at day 5th and day 31th.

However, significantly differences were found for the Salmonella Enteritidis count concerning the colonization of the gastrointestinal tract (ileum pool, cecum, and cecal tonsils) at 5 and 31 days of age. The difference between the levels of

Table 2. Mean and standard deviation of Salmonella Enteritidis cell count (MPN/g) in ileum, cecum, and cecal tonsils pool and liver, heart and spleen pool, at 5 and 31 days of age in different treatments

\begin{tabular}{|c|c|c|c|c|}
\hline \multirow{2}{*}{ Treatment } & \multicolumn{2}{|c|}{ MPN/g Ileum, Cecum, and Cecal Tonsils Pool } & \multicolumn{2}{|c|}{ MPN/g Heart, Liver and spleen Pool } \\
\hline & 5 days & 31 days & 5 days & 31 days \\
\hline $\mathrm{T} 1$ & $219.2 \pm 102.8 \mathrm{a}$ & $100.0 \pm 138.2 \mathrm{ab}$ & $100.0 \pm 162.5$ & $45.0 \pm 102.3 \mathrm{~b}$ \\
\hline $\mathrm{T} 2$ & $85.8 \pm 98 . \mathrm{b}$ & $17.5 \pm 37.2 \mathrm{~b}$ & $151.7 \pm 164.4$ & $126.7 \pm 133.8 \mathrm{a}$ \\
\hline $\mathrm{T} 3$ & $110.0 \pm 141.6 \mathrm{~b}$ & $143.3 \pm 147.8 \mathrm{ab}$ & $165.8 \pm 157.3$ & $165.8 \pm 126.0 \mathrm{a}$ \\
\hline $\mathrm{T} 4$ & $122.5 \mathrm{~b} \pm 133.8 \mathrm{~b}$ & $220.0 \pm 162.5 \mathrm{a}$ & $248.3 \pm 131.1$ & $145.0 \pm 126.6 \mathrm{a}$ \\
\hline $\mathrm{T} 5$ & $54.2 \pm 61.3 \mathrm{~b}$ & $30.8 \pm 94.9 \mathrm{~b}$ & $137.5 \pm 169.9$ & $98.3 \pm 129.5 \mathrm{ab}$ \\
\hline $\begin{array}{l}\text { Anova: } \\
\text { p-value }\end{array}$ & $0.001^{* *}$ & $0.024^{*}$ & & $0.016^{*}$ \\
\hline lâmbda & 0.22 & -0.10 & 0.03 & 0.12 \\
\hline
\end{tabular}


cecal colonization and invasion of liver may be due to factors of virulence of Salmonella colonization that are based on two Salmonella pathogenicity islands (SPI 1 and 2), responsible for intestinal infection (SPI 1) and systemic infection of the host (RLS 2) (Borsoi et al. 2011).

In Salmonella Enteritidis count related to the colonization of the gastrointestinal tract (ileum pool, cecal tonsils and cecum) at 5 days of age differences were found $(\mathrm{p} \leq 0.01)$ between treatment 1 (no probiotics) to the other treatments with probiotics (T2, T3, T4 and T5), but no differences ( $\mathrm{p} \geq 0.05$ ) between treatments with probiotics. Sn average decrease of $126 \mathrm{MPN} / \mathrm{g}$ (57.5\%) of Salmonella Enteritidis was obtained using probiotics, proving the effectiveness of all probiotics used to reduce the colonization of gastrointestinal tract by Salmonella Enteritidis.

Differences between treatments ( $\mathrm{p} \leq 0.05)$ were found in the Salmonella Enteritidis colonization counting in the digestive tract (ileum pool, cecal tonsils, and cecum) at 31 days of age. The treatment T2 with counting of $17.5 \mathrm{MPN} / \mathrm{g}$ and T5 with $30.8 \mathrm{MPN} / \mathrm{g}$ were statistically different $(\mathrm{p} \leq 0.05)$ from control T1 and the probiotic T3 and T4, being the most effective probiotics in control of the colonization of the gastrointestinal tract by Salmonella Enteritidis. Moreover, T2 (defined probiotic culture) and $\mathrm{T} 5$ (undefined probiotic culture) decreased on average 82.5 MPN/g and 69.2 MPN/g, respectively, compared to treatment without probiotic. Borsoi et al. (2010) verifying the presence and estima the MPN in Salmonella cells using the MPNmethod (MPN/carcasses) in 180 chicken carcasses cooled from three different brands purchased from retailers found $64.7 \%$ of the samples between $11-100$ cells and $35.3 \%$ between $101-1100$ cells.

In Table 3 are shown the results from comparison of different probiotic compositions. Differences $(\mathrm{p} \leq 0.01)$ were found at 5 days of age among the probiotics groups of defined culture and undefined culture and treatment without probiotic, but no difference $(\mathrm{p} \geq 0.05)$ between the constitutions of probiotics. The results demonstrate that there is no difference in the structure of probiotics on defined and undefined cultures, but both are useful in the control of Salmonella Enteritidis. Different results found by Estrada et al. (2010) showed that defined culture probiotics have greater effectiveness than the undefined culture of probiotics.

Table 3. Comparison of the averages in counting of Salmonella Enteritidis, by the Most Probable Number method of bacterial cells per gram (MPN/g), in ileum pool, cecum, and cecal tonsils at 5 and 31 days of age between treatments without probiotics (T1), probiotics of defined cultures (T2+T3) and probiotics of undefined cultures (T4+T5)

\begin{tabular}{ccc}
\hline \multirow{2}{*}{ Treatment } & \multicolumn{2}{c}{ MPN - Ileum, Cecal Tonsils, and Cecum } \\
\cline { 2 - 3 } & 5 days & 31 days \\
\hline T1 (Without probiotics) & $219.2 \pm 102.8 \mathrm{a}$ & $100.0 \pm 138.2$ \\
Defined culture & $97.9 \pm 120.1 \mathrm{~b}$ & $80.4 \pm 123.5$ \\
Undefined culture & $88.3 \pm 107.6 \mathrm{~b}$ & $125.4 \pm 80.4$ \\
Anova: -value & $0.002^{* *}$ & \\
Lambda & 0.20 & -0.10
\end{tabular}

** Significant at 1\% probability, Averages followed by different letters in the same column differ statistically by $5 \%$ in the Scheffé Test.

\section{CONCLUSIONS}

All probiotics used were effective in reducing Salmonella Enteritidis colonization in the ileum, tonsil cecais and cecos to 5 days of age and only the probiotics of T2 (culture defined-lyophilized form, 7 strains) and T5 (indefinite-lyophilized culture) reduced the settlement to the 31 days of age being considered the most useful in the control of Salmonella Enteritidis in these intestinal segments evaluated.

Our results did not found significantly differences regarding zootechnic performance and it can not be said which of the constitutions of probiotics evaluated in this work, defined or undefined cultures, are more efficient in controlling Salmonella Enteritidis.

\section{REFERENCES}

Al-Zenki S.F., Al-Nasser A.Y., Al-Saffar A.E., Abdullah F.K., Al-Bahouh M.E., Al-Haddad A.S., Alomirah H. \& Mashaly M. 2009. Effects of using a chickenorigin competitive exclusion culture and probiotic cultures on reducing Salmonella in broilers. J. Appl. Poult. Res. 18(1):23-29. http://dx.doi. org/10.3382/japr.2008-00036.

Berndt A., Pieper J. \& Methner U. 2006. Circulating gamma delta t cells in response to Salmonella enterica serovar Enteritidis exposure in chickens. Infect. Immun. 74(7):3967-3978. PMid:16790770. http://dx.doi. org/10.1128/IAI.01128-05.

Bittencourt L.C., Silva C.C., Garcia P.D.S.R., Donato D.C.Z., Albuquerque R. \& Araújo L.F. 2011. Influence of a probiotic on broiler performance. Rev. Bras. Zootec. 40(12):2739-2743. http://dx.doi.org/10.1590/S151635982011001200018.

Bopp C.A., Brenner F.W., Wells J.G. \& Strockbine N.A. 2003. Escherichia coli, Shigella and Salmonella. Manual of Clinical Microbiology. Washington, p.459-474.

Borsoi A., Moraes L.L.S., Salle C.T.P. \& Nascimento V.P. 2010. Número mais provável de Salmonella isoladas de carcaças de frango resfriadas. Cienc. Rural 40(11):2338-2342. http://dx.doi.org/10.1590/S0103-84782010001100014.

Borsoi A., Santos L.R., Rodrigues L.B., Moraes H.l.S., Salle C.T.P. \& Nascimento V.P. 2011. Behavior of salmonella heidelberg and salmonella enteritidis strains following broiler chick inoculation: evaluation of cecal morphometry, liver and cecum bacterial counts and fecal excretion patterns. Braz. J. Microbiol. 42(1):266-273. http://10.1590/S1517-83822011000100034

DeMan J.C. 1983. MNP tables, corrected. Eur. J. Appl. Microbiol. 17(5):301305. http://dx.doi.org/10.1007/BF00508025.

Estrada M.A.J., Hernández J.A.M. \& Soto L.G. 2010. Un probiótico definido aumenta la exclusión de Salmonella enterica serovariedad Enteritidis durante la crianza de aves ligeras. Revta Vet. Mex. 41:25-43.

Gaggìa F., Mattarelli P. \& Biavati B. 2010. Probiotics and prebiotics in animal feeding for safe food production. Int. J. Food Microbiol. 141(suppl. 1):S15-S28 PMid:20382438. http://dx.doi.org/10.1016/j.ijfoodmicro.2010.02.031.

Gast R.K., Guraya R., Guard-Bouldin J., Holt P.S. \& Moore R.W. 2007. Colonization of specific regions of the reproductive tract and deposition at different locations inside eggs laid by hens infected with Salmonella Enteritidis or Salmonella Heidelberg. Avian Dis. 51(1):40-44. PMid:17461265. http:// dx.doi.org/10.1637/0005-2086(2007)051[0040:COSROT]2.0.CO;2.

Guibourdenche M., Roggentin P., Mikoleit M., Fields P.I., Bockemühl J., Grimont P.A.D. \& Weill F.X. 2010. Supplement 2003-2007 (No. 47) to the WhiteKauffmann-Le Minor scheme. Res. Microbiol.161(1):26-29. PMid:19840847. http://dx.doi.org/10.1016/j.resmic.2009.10.002.

Hasenstein J.R., Zhang G. \& Lamont S.J. 2006. Analyses of five gallinacin genes and the Salmonella enterica serovar Enteritidis response in poultry. Infect. Immun. 74(6):3375-3380. PMid:16714567. http://dx.doi.org/10.1128/ IAI.00027-06 
Koerich P.K.V. 2007. Detecção de Salmonella em reprodutoras de frango: comparação entre Real Time PCR e dois métodos microbiológicos (SemiSólido Rappaport-Vassiliadis e Duplo Enriquecimento). Dissertação de Mestrado em Diagnóstico Genético e Molecular, Universidade Luterana do Brasil, Canoas, RS. 30p.

Lutful Kabir S.M. 2009. The role of probiotics in the poultry industry. Int. J. Mol. Sci. 10(8):3531-3546. PMid:20111681. http://dx.doi.org/10.3390/ ijms10083531.

MAPA 2003. Métodos analíticos oficiais para análises microbiológicas para controle de produtos de origem animal e água. Instrução Normativa SDA N.62, de 26 de agosto de 2003. Diário da República Federativa do Brasil. Secretaria da defesa Agropecuária, Ministério da Agricultura, Pecuária e Abastecimento, Brasília.

Miragliotta M.Y. 2005. Avaliação das condições do ambiente interno em dois galpões de produção comercial de frangos de corte, com ventilação e densidade populacional diferenciados. Tese de Doutorado em Construções Rurais e Ambiência, Universidade Estadual de Campinas, Campinas, São Paulo. 42p.

Mountzouris K.C., Tsitrsikos P., Palamidi I., Arvaniti A., Mohnl M., Schatzmayr G. \& Fegeros K. 2010. Effects of probiotic inclusion levels in broiler nutrition on growth performance, nutrient digestibility, plasma immunoglobulins, and cecal microflora composition. Poult. Sci. 89(1):58-67. PMid:20008803. http://dx.doi.org/10.3382/ps.2009-00308.

Pickler L., Hayashi R.M., Lourenço M.C., Miglino L.B., Caron L.F., Beirão B.C.B., Silva A.V.F. \& Santin E. 2012. Avaliação microbiológica, histológica e imunológica de frangos de corte desafiados com Salmonella Enteritidis e Minnesota e tratados com ácidos orgânicos. Pesq. Vet. Bras. 32(1):27-36. http://dx.doi.org/10.1590/S0100-736X2012000100006.

Pickler L., Santin E. \& Silva A.V.F. 2011. Alternativas aos antibióticos para equilibrar a microbiota gastrointestinal de frangos. Archs Vet. Sci. 16:1-13.

R Development Core Team 2005. R: A language and environment for statistical computing. R Foundation Stat. Computing, ISBN 3-900051-07-0. Available at 2005: http://www.r-project.org

Rahimi S., Shiraz Z.M., Salehi T.Z., Torshizi M.A.K. \& Grimes J.L. 2007. Prevention of salmonella infection in poultry by specific egg-derived antibody. Int. J. Poult. Sci. 6(4):230-235.
Revolledo L., Ferreira A.J.P. \& Mead G.C. 2006. Prospects in Salmonella control: Competitive exclusion, probiotics, and enhancement of avian intestinal immunity. J. Appl. Poult. Res. 15(2):341-351. http://dx.doi.org/10.1093/ japr/15.2.341.

Revolledo L., Ferreira C.S.A. \& Ferreira A.J.P. 2009. Prevention of Salmonella Typhimurium colonization and organ invasion by combination treatment in broiler chicks. Poult. Sci. 88(4):734-743. PMid:19276416. http://dx.doi. org/10.3382/ps.2008-00410.

Rossi A.A., Padilha M.T.S., Santos I.I. \& Padilha J.C.F. 2007. Uso de probiótico na prevenção de Salmoneloses em frangos de corte. Ciência Agrotécnica. Lavras 31(4):1207-1211.

Rostagno H.S., Albino L.F.T., Donzele J.L., Gomes P.C., Oliveira R.F., Lopes D.C., Ferreira A.S., Barreto S.L.T. \& Euclides R.F. 2005. Tabelas Brasileiras para Aves e Suínos: composição de alimentos e exigências nutricionais. $2^{\underline{a}}$ ed. UFV, Viçosa, Minas Gerais.

Schrezenmeir J. \& Devrese A.M. 2001. Probiotics, prebiotics and symbiotics: approaching a definition. Am. J. Clin. Nutr. 73(2, suppl. ):361S-364S. PMid:11157342.

Silva W.T.M., Nunes R.V., Pozza P.C., Pozza M.S.S., Appelt M.D. \& Eyng C. 2011. Avaliação de inulina e probiótico para frangos de corte. Acta Sci. Anim. Sci. 33(1):19-24. http://dx.doi.org/10.4025/actascianimsci.v33i1.9979.

Tellez G., Pixley C., Wolfenden R.E., Layton S.L. \& Hargis B.M. 2012. Probiotics/ direct fed microbials for Salmonella control in poultry. Food Res. Int. 45(2):628-633. http://dx.doi.org/10.1016/j.foodres.2011.03.047.

Vicente J., Higgins S., Bielke L., Tellez G., Donoghue D., Donoghue A. \& Hargis B. 2007. Effect of probiotic culture candidates on Salmonella prevalence in commercial turkey houses. J. Appl. Poult. Res. 16(3):471-476. http:// dx.doi.org/10.1093/japr/16.3.471.

Vicente J., Torres-Rodriguez A., Higgins S., Pixley C., Tellez G., Donoghue A.M. \& Hargis B.M. 2008. Effect of a selected Lactobacillus spp-based probiotic on Salmonella Enteritidis-infected broiler chicks. Avian Dis. 52(1):143146. PMid:18459312. http://dx.doi.org/10.1637/7847-011107-ResNote. 